\title{
Meningkatkan Pemahaman Tentang Jajanan Sehat Dalam Kemasan Melalui Informasi Pada Label Kemasannya Bagi Siswa SDN I Jatisela
}

\author{
Kusmiyati ${ }^{*}$, Dewa Ayu Citra Rasmi ${ }^{1}$, Tri Ayu Lestari ${ }^{1}$

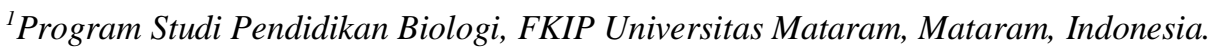

DOI: https://doi.org/10.29303/jpmsi.v2i2.69

Citation: Kusmiyati, K., Rasmi, D., A., C., Lestari, T., A. 2020. Meningkatkan Pemahaman Tentang Jajanan Sehat Dalam Kemasan Melalui Informasi Pada Label Kemasannya Bagi Siswa SDN I Jatisela. Jurnal Pengabdian Masyarakat Sains Indonesia (JPMSI). 2(2): 113-118.

\section{Article history}

Received: October $16^{\text {th }} 2020$

Revised: October $24^{\text {th }} 2020$

Accepted: November $2^{\text {th }} 2020$

*Corresponding Author:

Kusmiyati, FKIP Universitas

Mataram, Mataram, Indonesia. Email:

kusmiyati0112@gmail.com

\begin{abstract}
Abstrak: Memasuki usia sekolah, anak mulai ingin menunjukkan kemampuannya menentukan pilihan atas makanan. Maraknya jenis jajanan kemasan untuk anak, anak sekolah menjadi lebih mudah mendapatkan jajanan di luar rumah. Kegiatan pengabdian ini diharapkan dapat meningkatkan pemahaman siswa SDN I Jatisela tentang jajanan sehat dalam kemasan, sehingga mereka dapat menentukan jenis jajanan yang sehat, bergizi dan aman untuk dikonsumsi, serta dapat menerapkan pengetahuannya dalam kehidupan sehari-hari. Kegiatan pengabdian ini dilaksanakan dengan metode sebagai berikut: a).Metode ceramah, digunakan untuk menyampaikan pengetahuan tentang jajanan sehat dan bergizi meliputi: Unsur gizi dalam makanan dan bahan tambahan makanan. b). Metode praktek, digunakan untuk praktek membandingkan 2 macam jajanan yang biasa dikonsumsi, secara berkelompok dengan setiap kelompok beranggotakan 2 orang anak. c). Metode tanya jawab, digunakan untuk memberikan umpan balik pada siswa sekaligus untuk mendapatkan tanggapan siswa tentang materi yang telah disampaikan selama kegiatan. Antusias siswa pada saat pelaksanaan kegiatan sangat tinggi, terlihat pada waktu pretes semua siswa mengerjakan dengan sungguh-sungguh. Selanjutnya ketika penyampaian materi, siswa juga dapat diajak interaksi, dengan mengajukan pertanyaan dari materi yang disampaikan. Rata-rata hasil pretes sebesar 78,57 dan rata-rata postes sebesar 89,09. Hasil penghitungan gain ternormalisasi, menunjukkan pengetahuan jajanan sehat dalam kemasan siswa meningkat dengan kategori sedang. Siswa dapat menemukan informasi penting yang harus diperhatikan pada label kemasan. Kesimpulan dari kegiatan ini adalah: (1) Antusias siswa sangat tinggi, semua siswa mengikuti kegiatan dari awal sampai akhir; (2) Pengetahuan siswa tentang jajanan sehat dalam kemasan meningkat. Saran dari kegiatan pengabdian ini adalah pengabdian ini dapat dilakukan di sekolah lain, agar siswa mempunyai pengetahuan jajanan sehat, sehingga dapat mencegah terjadinya gizi salah pada anak
\end{abstract}

Kata kunci: Jajanan, Kemasan.

kurangnya asupan sumber zat gizi yang dibutuhkan anak, anak tidak mengonsumsi gizi seimbang, tidak sarapan dan jajanan yang tidak sehat. Pengetahuan keluarga akan gizi sangat mempengaruhi perilaku anak untuk mengonsumsi suatu makanan.

Berat badan merupakan salah satu indikator status gizi anak. Anak dengan status gizi ideal, berat badannya juga diposisi berat ideal menurut umur. Bagi anak yang terbiasa memilih-milih makanan kesukaan tanpa mempertimbangkan zat gizi yang terkandung di dalamnya, akan 
Kusmiyati et al, Jurnal Pengabdian Masyarakat Sains Indonesia 2020, 2 (2): 103-118. DOI : https://doi.org/10.29303/jpmsi.v2i2.69

menyebabkan terhambatnya pertambahan berat dan tinggi badan. Untuk mendapatkan status gizi yang baik diperlukan pengetahuan gizi bagi setiap anggota keluarga, agar dapat menyediakan menu pilihan dengan gizi seimbang, termasuk memilih jajanan.

Memasuki usia sekolah, anak mulai ingin menunjukkan kemampuannya menentukan pilihan atas makanan. Melihat banyaknya pilihan jajanan dalam kemasan, anak mulai tidak mudah lagi diatur dengan makanan yang biasa disediakan orang tua di rumah. Sejalan dengan itu, gizi anak sekolah sering terabaikan, karena orang tua beranggapan anak sudah besar dan mampu memilih jajanan sendiri.

Beberapa faktor yang berpengaruh dalam pemilihan jajanan sehat, antara lain pengetahuan anak tentang zat gizi, kebiasaan makan di rumah, ketidaktahuan dan sebagainya. Sibagariang (2010) menyebutkan, lingkungan yang kurang baik juga dapat mempengaruhi gizi pada anak, sebagai contoh seringnya anak jajan sembarangan di tepi jalan, karena melihat teman-temannya yang juga sedang jajan sembarangan. Kurangnya pengetahuan tentang gizi menjadikan anak membeli makanan tanpa tahu apakah makanan tersebut mengandung gizi cukup atau tidak.

Pengabdian serupa telah dilakukan di SDN I Tamansari, dengan hasil peserta (siswa) cukup antusias, terlihat dari banyaknya pertanyaan pada saat diskusi, dan disarankan pengabdian yang sama perlu disampaikan pada siswa Sekolah Dasar lain agar perilaku gizi salah dapat teratasi (Kusmiyati, dkk., 2016)

\section{b. Permasalahan Masyarakat Sasaran}

Maraknya jenis jajanan kemasan untuk anak, anak sekolah menjadi lebih mudah untuk mendapatkan jajanan di luar rumah. Ketidaktahuan menyebabkan anak kurang memperhatikan jajanan yang sehat dan aman, yang penting enak. Ketidaktahuan akan gizi yang baik pada anak menyebabkan anak sering berperilaku salah dalam mengonsumsi zat gizi.

\section{c. Solusi}

Kegiatan pengabdian ini bertujuan meningkatkan pemahaman tentang jajanan sehat dalam kemasan melalui informasi pada label kemasannya bagi siswa SDN I Jatisela. Sesuai permasalahan yang telah diuraikan di atas, maka meningkatkan pemahaman tentang jajanan sehat dengan memperhatikan kandungan gizi atau informasi lain dalam label kemasannya menjadi solusi yang tepat, agar anak dapat memilih jajanan
e-ISSN : 2715-2537

p-ISSN : 2715-2545

dalam kemasan yang bergizi dan sehat. Melalui pengabdian ini anak dilatih untuk memilih jajanan sehat, bergizi dan aman. Diharapkan anak bisa menceritakan kepada orang tua tentang pengetahuannya, dan tidak sembarangan dalam memilih jajanan dalam kemasan.

\section{Metode}

Kegiatan pengabdian ini berlangsung dalam tahapan-tahapan, meliputi:

a. Tahap persiapan, pada tahap ini diadakan persiapan tentang pembagian tugas anggota tim penyuluhan agar semaksimal mungkin dapat memberikan pengetahuan dan pemahaman yang memadai bagi siswa/ peserta penyuluhan. Selanjutnya mencari referensi untuk menyusun materi yang harus disampaikan ke peserta, menyusun instrument untuk pretes dan postes, menyusun lembar kerja untuk kegiatan praktek. Pada tahap ini juga digunakan untuk menyusun daftar hadir peserta, menyiapkan alat bahan untuk praktek.

b. Tahap observasi, pada tahap ini diadakan konsultasi dengan pihak sekolah tentang faktor-faktor yang mendukung dan menghambat pelaksanaan kegiatan penyuluhan, sehingga dapat dicarikan alternatif yang terbaik dalam pelaksanaannya. SDN 1 Jatisela terletak di desa Jatisela Lombok Barat. Hasil observasi pertama diperoleh informasi sebagai berikut, dalam situasi pandemi Covid-19, SDN 1 Jatisela juga melakukan protokol kesehatan sesuai anjuran dinas pendidikan Lombok Barat. Proses pembelajaran hanya dilakukan dalam kelompok kecil di rumah siswa, yang dikunjungi oleh guru dan hanya gurunya yang boleh mendatangi kelompok tersebut. Aturan ini berlaku hingga tanggal 14 September 2020. Oleh karena itu, tim pengabdian belum bisa melaksanakan kegiatan pengabdian ini dan harus kembali ke Sekolah tanggal 17 September 2020, memastikan bagaimana pelaksanaan pengabdian ini, mencari solusi dengan mempertimbangkan hasil konsultasi dengan dinas pendidikan Lombok Barat. Akhirnya disepakati pelaksanaan pengabdian pada tanggal 23 September 2020.

c. Tahap pelaksanaan kegiatan, pada tahap ini disampaikan materi tentang jajanan sehat 
Kusmiyati et al, Jurnal Pengabdian Masyarakat Sains Indonesia 2020, 2 (2): 103-118. DOI : https://doi.org/10.29303/jpmsi.v2i2.69

dalam kemasan. Waktu pelaksanaan disesuaikan dengan kesepakatan antara anggota tim pengabdian dengan pihak sekolah tempat sasaran kegiatan. Urutan pelaksanaan kegiatan pengabdian ini adalah Tim pengabdian memperkenalkan diri dan menyampaikan tujuan pengabdian ini. Siswa mengisi daftar hadir, dan mengerjakan tes awal (pretes). Siswa dibagi menjadi 10 kelompok masing-masing kelompok terdiri dari 2-3 orang. Selanjutnya penyampaian materi oleh tim pengabdian,setelah itu peserta melakukan praktek identifikasi jajanan sehat dalam kemasan, dan persentasi hasilnya di depan kelas diwakili beberapa kelompok. Terakhir peserta mengerjakan tes sesudah (postes) penyampaian materi.

d. Tahap penyusunan laporan, pada tahap ini dilakukan penyusunan laporan kegiatan pengabdian sesuai dengan uraian materi yang disampaikan pada saat pelaksanaan pengabdian. Untuk mengetahui peningkatan pengetahuan siswa tentang pemilihan jajanan sehat dalam kemasan, dilakukan tes awal (pretes) dan tes akhir (postes) menggunakan instrument tes. Instrumen tes disusun berdasarkan indikator pemilihan jajanan sehat, kemudian disusun deskriptor dan soal tesnya. Hasil tersebut kemudian di di analisis untuk melihat peningkatan pengetahuan menggunakan rumus gain ternormalisasi $(\mathrm{g})$.

Kegiatan pengabdian ini dilaksanakan dengan metode sebagai berikut:

a. Metode ceramah, digunakan untuk menyampaikan pengetahuan tentang jajanan sehat dan bergizi meliputi: Unsur gizi dalam makanan dan bahan tambahan makanan, serta informasi label keamanan jajanan kemasan untuk dikonsumsi. Penyampaian ini dilakukan dengan memberikan contoh konkret, membaca informasi pada label kemasan jajanan yang biasa dikonsumsi anak.

b. Metode praktek, digunakan untuk praktek membandingkan 2 macam jajanan yang biasa dikonsumsi. Praktek ini dilakukan secara berkelompok dengan setiap kelompok beranggotakan 2 orang anak. Masing-masing kelompok bertugas mengidentifikasi informasi kandungan gizi, keamanan (tanggal kadaluwarsa), bahan tambahan makanan yang ditambahkan dan mencari informasi lain yang
e-ISSN : 2715-2537

p-ISSN : 2715-2545

ada pada label kemasan yang berhubungan dengan kesehatan. Selanjutnya peserta diminta untuk menceritakan jajanan mana yang lebih baik untuk dikonsumsi.

c. Metode tanya jawab, digunakan untuk memberikan umpan balik pada peserta sekaligus untuk mendapatkan tanggapan peserta tentang materi yang telah disampaikan selama kegiatan.

\section{Hasil dan Pembahasan}

Kegiatan pengabdian pada masyarakat ini dapat berjalan lancar, berkat dukungan dari pihak sekolah, yang memberikan kesempatan tim melaksanaakan pengabdian, meskipun dalam situasi pandemi covid-19. Penentuan waktu pelaksanaan pengabdian sangat lama karena harus menyesuaikan dengan edaran Dinas Pendidikan Lombok Barat, pembelajaran hanya boleh dilakukan dalam kelompok kecil dan hanya boleh dikunjungi oleh gurunya. Pihak sekolah dalam hal ini Kepala Sekolah tidak mengijinkan tim pengabdian melaksanakan pengabdian ini sampai tanggal 14 September 2020, karena tanggal tersebut merupakan batas akhir edaran Dinas Pendidikan Lombok Barat tentang penanggulangan penyebaran covid-19. Setelah tanggal tersebut akan disepakati waktu pelaksanaan disesuaikan dengan situasi dan kondisi penanganan covid-19. Tim pengabdian harus kembali ke sekolah pada tanggal 17 September 2020, untuk membuat kesepakatan ulang bisa tidaknya pengabdian dilaksanakan. Akhirnya disepakati pengabdian ini dilaksanakan pada hari Rabu tanggal 23 September 2020 pukul 9.00-10.30 WITA.

Kegiatan pengabdian ini dilaksanakan dengan surat perjanjian dari LPPM Universitas Mataram dan surat tugas dari fakultas. Pelaksanaan dilakukan di luar sekolah dengan tetap menjalankan protokol kesehatan menanggulangi penularan covid-19. Pihak sekolah menyediakan tempat di lapangan olahraga, siswa duduk lesehan di lapangan. Duduk diberi jarak, semua tim pengabdian menggunakan masker, tidak melakukan jabat tangan. Peserta yang menjadi sasaran pengabdian ini adalah siswa kelas 5 dengan jumlah siswa 23 orang, semua siswa hadir dan siswa yang hadir mengikuti kegiatan dari awal hingga akhir, pretes dan postes diikuti oleh semua siswa yang hadir. 
Kusmiyati et al, Jurnal Pengabdian Masyarakat Sains Indonesia 2020, 2 (2): 103-118. DOI : https://doi.org/10.29303/jpmsi.v2i2.69

Antusias peserta pada saat pelaksanaan kegiatan sangat tinggi, terlihat pada waktu pretes semua peserta mengerjakan dengan sungguhsungguh. Selanjutnya ketika penyampaian materi, peserta juga dapat diajak interaksi, dengan mengajukan pertanyaan dari materi yang disampaikan. Ketika kegiatan praktek mengidentifikasi atau membaca label kemasan dan memilah mana jajanan yang aman dan sehat untuk dikonsumsi, semua kelompok antusias dan bersungguh-sungguh mengerjakan tugas yang diberikan. Mereka ingin menjadi yang nomer satu, ketika diminta membacakan hasil kerja kelompoknya. Antusias mereka juga terlihat ketika mengerjakan postes, semua mengerjakan dengan sungguh-sungguh dan bekerja sendiri-sendiri, sehingga situasi tidak gaduh.

Rata-rata hasil tes yang dilakukan sebelum penyampaian materi (pretes) sebesar 78,57 dan rata-rata hasil tes setelah diberikan materi (postes) sebesar 89,09. Hasil penghitungan gain ternormalisasi sebesar 0,49 . Hal ini berarti bahwa pengetahuan jajanan sehat dalam kemasan peserta (siswa) meningkat dengan kategori sedang. Siswa dapat menemukan informasi penting yang harus diperhatikan pada label kemasan, ketika membeli jajanan dalam kemasan. Hal-hal tersebut antara lain tanggal kadaluwarsa, informasi kandungan gizi, kandungan gizi per sajian, komposisi bahan tambahan makanan yang ditambahkan, informasi alergen, kode halal dari MUI, kode BPOM RI, kode produksi, dan kode SNI. Informasi tersebut kemudian digunakan untuk menentukan pemilihan jajanan dalam kemasan yang aman dan sehat.

Sasaran pengabdian ini adalah siswa kelas tinggi yaitu kelas V SDN 1 Jatisela. SDN 1 Jatisela terletak di jalan raya Sesela kearah Ampenan. Proses pembelajaran di SDN 1 Jatisela, selama masa covid 19 dilakukan secara luring, guru mendatangi rumah siswa, oleh karena itu pelaksanaan pengabdian ini juga menyesuaikan protokol dari dinas pendidikan Lombok Barat. Sasaran pengabdian ini diambil kelas tinggi, karena tentunya mereka sudah lancar baca tulis dan mudah diajak komunikasi. Mereka juga sudah mendapatkan materi IPA yang di dalamnya sudah ada pengenalan tentang gizi. Selain itu, mereka belum pernah mendapatkan penyuluhan atau pelatihan tentang gizi, sehingga kegiatan ini ditanggapi positif oleh pihak sekolah. Siswa yang mengikuti juga sangat antusias, walaupun dilakukan di lapangan dengan lesehan.
e-ISSN : $2715-2537$

p-ISSN : 2715-2545

Hasil penghitungan gain ternormalisasi diperoleh sebesar 0,49 dan hasil ini menunjukkan bahwa pengetahuan siswa tentang jajanan dalam kemasan meningkat, dalam kategori sedang. Peningkatan pengetahuan ini dapat dipahami, dengan adanya penyampaian materi (bahan ajar jajanan sehat) dari tim pengabdian, yang dilanjutkan dengan praktek membaca informasi di label kemasan, menjadikan ingatan siswa lebih lama. Seperti pendapat Depdiknas (2008), bahan ajar antara lain bermanfaat dalam:(a) membangun komunikasi yang efektif antara guru dan siswa, (b) Membantu pelaksanaan kegiatan belajar mengajar, (c) Pembelajaran menjadi menarik, (d). memudahkan siswa memahami materi.

Kegiatan pengabdian ini melatih anak untuk memilih jajanan sehat, bergizi dan aman. Diharapkan anak bisa menceritakan kepada orang tua tentang pengetahuannya, dan tidak sembarangan dalam memilih jajanan dalam kemasan. Kebiasaann anak mengkonsumsi jajanan sembarangan disebabkan ketidaktahuan tentang fungsi zat gizi bagi tubuh. Ketidaktahuan akan gizi yang baik pada anak menyebabkan anak sering berperilaku salah dalam mengonsumsi zat gizi. Berikut beberapa perilaku gizi yang salah pada anak sekolah (Devi, 2012): a) Tidak mengonsumsi menu gizi yang seimbang, menu gizi yang seimbang seharusnya menjadi pedoman bagi pola makan anak sekolah. (b) Tidak sarapan pagi, makan pagi mempunyai peranan penting bagi anak sekolah usia 6-14 tahun, yaitu untuk pemenuhan gizi di pagi hari di mana anak-anak berangkat ke sekolah dan mempunyai aktivitas yang sangat padat di sekolah, (c) Jajan tidak sehat di sekolah, anak sekolah tidak bisa terlepas dari makanan jajanan di sekolah, (d) Kurang mengonsumsi buah dan sayur, buah dan sayur merupakan sumber zat gizi vitamin dan mineral, (e) Mengonsumsi fast food dan junk food, fast foot adalah istilah yang diberikan untuk makanan yang dapat disusun dan disajikan dengan cepat. Sedangkan junk food mendiskripsikan makanan tidak sehat atau memiliki sedikit mengandung kandungan nutrisi, (e) Mengonsumsi makanan berisiko, yang termasuk makanan yang berisiko adalah penyedap makanan (MSG), makanan berkafein, makanan yang diberi pengawet, dan bahan pewarna yang dilarang, (f) Konsumsi gula berlebihan, gula ditemukan secara alami dalam buah-buahan (fruktosa) dan susu cair dan produk susu (laktosa), (g) Konsumsi lemak berlebihan, 
Kusmiyati et al, Jurnal Pengabdian Masyarakat Sains Indonesia 2020, 2 (2): 103-118. DOI : https://doi.org/10.29303/jpmsi.v2i2.69

lemak makanan terdapat pada tumbuhan dan hewan.

Santosa dan Ranti (2009), menyebutkan fungsi lemak bagi tubuh selain sebagai pemberi kalori, juga sebagai pembentukan membran sel, memberikan asam lemak esensial dan melarutkan vitamin. Sibagariang (2010) menambahkan, fungsi lemak adalah memberi rasa gurih dan renyah pada makanan yang digoreng, memberikan sifat empuk pada kue yang dibakar, pelindung organ tubuh,memelihara suhu tubuh dan sebagai sumber asam lemak tak jenuh. Lemak juga merupakan zat yang digunakan bagi tubuh untuk memproduksi prostaglandin yaitu hormone yang berperan mengatur tekanan darah, system saraf, denyut jantung, kontriksi pembuluh darah, dan pembekuan darah. Lemak juga memelihara kulit, rambut, melindungi organ penting dan memelihara tubuh tetap hangat.

Mengkonsumsi makanan yang berlemak, rasa kenyang yang kita rasakan akan bertahan lebih lama, namun mengonsumsi makanan tinggi lemak memberikan efek buruk bagi kesehatan, meningkatkan resiko terkena jantung coroner, kolesterol darah, diabetes dan beberapa jenis kanker. Obesitas, penyakit batu empedu, liver, osteoarthritis juga dipicu oleh karena konsumsi tinggi lemak. Apabila dalam makanan kita kelebihan karbohidrat atau lemak yang diperlukan tubuh, maka akan diubah menjadi lemak dan disimpan sebagai cadangan tenaga yang sewaktuwaktu diambil jika diperlukan tubuh. Pudjiati (2001) menyebutkan, lemak cadangan disimpan di bawah kulit, di sekitar otot-otot dan alat-alat tubuh yang lain. Kumpulan lemak di sekitar alat tubuh berfungsi untuk menjaga agar alat tubuh tersebut terdapat pada posisinya, misalnya lemak di sekitar rongga mata, yang berguna sebagai bantalan biji mata.

Siswa terlihat bersemangat mengikuti kegiatan ini, siswa bisa membedakan jajanan kemasan yang aman dan sehat, dengan membaca informasi pada labelnya. Siswa dapat mengidentifikasi informasi di label kemasan, menggunakan lembar kerja pengamatan. Adanya lembar kerja ini siswa menjadi lebih terarah dan dapat memahami apa yang harus diperhatikan dalam memilih jajanan sehat dan aman. Lembar kerja peserta didik merupakan salah satu sarana untuk membantu dan mempermudah dalam kegiatan belajar mengajar, sehingga akan terbentuk interaksi yang efektif antara peserta didik dan
e-ISSN : 2715-2537

p-ISSN : 2715-2545

pendidik, dapat meningkatkan aktivitas peserta didik dan meningkatkan hasil belajar.

Kegiatan pengabdian ini membekali siswa pengetahuan tentang memilih jajanan dalam kemasan melalui informasi di labelnya, antara lain harus diperhatikan tanggal kadaluarsa, kode produksi, kode SNI, label halal dari MUI, komposisi zat gizi, komposisi bahan tambahan makanan, informasi alergen dan kandungan gizi per sajian. Akhirnya dengan praktek dua macam jajanan siswa dapat membedakan jajanan mana yang lebih baik dari segi kandungan gizi dan lainnya di label kemasannya. Pengamatan komposisi bahan tambahan makanan yang digunakan menjadi penting, karena bahan yang ditambahkan pada makanan ada aturannya apalagi jika yang ditambahkan berupa bahan yang bukan diperuntukkan untuk makanan.

Bahan tambahan makanan (BTM) adalah bahan atau campuran bahan yang secara alami bukan merupakan bagian dari bahan baku pangan, tetapi ditambahkan kedalam pangan untuk mempengaruhi sifat atau bentuk pangan, antara lain bahan pewarna, pengawet, penyedap rasa, anti gumpal, pemucat dan pengental. Dalam Peraturan Menteri Kesehatan RI No. 722/Menkes/Per/IX/88 dijelaskan bahwa bahan tambahan makanan adalah bahan yang biasanya tidak digunakan sebagai pangan dan biasanya bukan merupakan ingredien khas pangan, mempunyai atau tidak mempunyai nilai gizi, yang dengan sengaja ditambahkan ke dalam pangan. Tujuan penggunaan bahan tambahan makanan adalah untuk meningkatkan dan mempertahankan nilai gizi dan kualitas makanan.

Tampilan jajanan dalam kemasan akan menjadi menarik jika ditambahkan dengan pewarna makanan, pewarna yang digunakan sudah semestinya dipilih yang diperuntukkan untuk makanan. Bahan pangan akan menjadi berwarna jika ditambahkan zat pewarna ke dalamnya. Pewarna makanan adalah bahan tambahan makanan yang dapat memperbaiki warna makanan yang berubah atau menjadi pucat selama proses pengolahan atau untuk memberi warna pada makanan yang tidak berwarna agar terlihat lebih menarik (Winarno, 1994). Berbagai jenis pangan dan minuman yang beredar di Indonesia, baik secara sengaja maupun tidak sengaja telah diwarnai dengan pewarna tekstil atau pewarna yang bukan food grade, yang tidak diizinkan digunakan dalam bahan pangan (Cahyadi, 2009). Zat warna alami 
Kusmiyati et al, Jurnal Pengabdian Masyarakat Sains Indonesia 2020, 2 (2): 103-118. DOI : https://doi.org/10.29303/jpmsi.v2i2.69

adalah zat warna (pigmen) yang diperoleh dari tumbuhan, hewan, atau dari sumber-sumber mineral. Zat warna ini telah sejak dahulu digunakan untuk pewarna makanan dan sampai sekarang umumnya penggunaannya dianggap lebih aman daripada zat warna sintetis

Pengamatan informasi label kemasan dilakukan secara kelompok, hal ini dilakukan sekaligus untuk melatih anak mengembangkan sikapnya, atau mengembangkan karakter dirinya seperti kerjasama, kejujuran, tolong menolong, menerima pendapat orang lain, kebersamaan dan sebagainya. Dengan bekerja kelompok siswa dapat saling bekerjasama dan tolong menolong, mereka dapat mengembangkan nilai kebersamaan, bersama dengan siswa lain yang berbedabagama atau status social, untuk menghasilkan suatu kesimpulan. Selain itu siswa akan berlatih menghormati pendapat orang lain, ketika pendapat temannya berbeda dengan pendapatnya. Terkadang siswa terlihat ingin menang sendiri, ingin menunjukkan bahwa dirinya yang paling diantara temantemannya. Keadaan tersebut bisa dipahami, karena mereka masih anak-anak, yang masih harus terus dibantu, tidak hanya masalah kognitif dan keterampilan, tetapi juga sikapnya. Seperti pendapat Depdiknas (2008), penanaman sikap ilmiah dalam pembelajaran bertujuan agar siswa memiliki soft skill yang baik untuk masa yang akan dating dan secara tidak langsung akan menjadi karakter siswa. Sikap tersebut meliputi nilai kebersamaan dalam belajar, kejujuran, kasih saying, tolong menolong, minat belajar, semangat bekerja dan bersedia menerima pendapat oranglain.

\section{Kesimpulan}

Kesimpulan dari kegiatan ini adalah: (1) Antusias siswa sangat tinggi, semua siswa mengikuti kegiatan dari awal sampai akhir; (2) Pengetahuan siswa tentang jajanan sehat dalam kemasan meningkat, dalam kategori sedang.

\section{Saran}

Kegiatan pengabdian ini dapat dilakukan di sekolah lain, agar siswa mempunyai pengetahuan jajanan sehat, sehingga dapat mencegah terjadinya gizi salah pada anak.

\section{Ucapan Terima Kasih}

e-ISSN : 2715-2537 p-ISSN : $2715-2545$

Tim pengabdian mengucapkan terima kasih kepada Universitas Mataram dan LPPM UNRAM yang telah memfasilitasi kegiatan ini, dan juga kepada semua pihak yang telah mendukung pelaksanaan kegiatan ini.

\section{Daftar Pustaka}

Cahyadi., W. 2008. Analisi dan Aspek Kesehatan Bahan Tambahan Manakan. Jakarta. Bumi Aksara

Depdiknas. 2008. Kurikulum Tingkat satuan pendidikan, Jakarta Dikmenum

Devi, N. 2012. Anak Sekolah. Jakarta. Kompas

Kusmiyati, dkk. 2016. Penyuluhan tentang pemilihan jajanan sehat pada siswa SDN 1 Tamansari Laporan pengabdian pada masyarakat, LPPM Unram. Mataram

Pudjiati S.2001. Ilmu Gizi klinis pada anak. Jakarta. FKUI

Peraturan Menteri Kesehatan RI No. 722/MenKes/Per/IX/1988. Bahan Tambahan Makanan

Santosa, S. dan Ranti, A.L. 2009, Kesehatan \& Gizi , Jakarta, Rineka Cipta

Sibagariang, E.E., 2010, Gizi Dalam Kesehatan Reproduksi, Jakarta, Trans Info Media,

Winarno, F., G., dan Rahayu. 1994. Bahan tambahan makanan Untuk Pangan danKontaminan. Cet 1. Jakarta. Pustaka Sinar Harapan 